\title{
Performance of confined sheep fed diets based on silages of different sorghum cultivars
}

\section{Desempenho produtivo de ovinos em confinamento alimentados com dietas à base de silagens de diferentes cultivares de sorgo}

\author{
PINHO, Ricardo Martins Araujo ${ }^{1 *}$; SANTOS, Edson Mauro ${ }^{2}$; OLIVEIRA, Juliana Silva \\ $\mathrm{de}^{2}$; PERAZZO, Alexandre Fernandes ${ }^{3}$; SOUSA, Wandrick Hauss de ${ }^{4}$; RAMOS, João \\ Paulo de Farias ${ }^{4}$; CARVALHO, Gleidson Giordano Pinto de ${ }^{3}$; PEREIRA, Gildênia \\ Araújo $^{2}$
}

\author{
${ }^{1}$ Universidade Federal de Viçosa, Viçosa, Minas Gerais, Brasil. \\ ${ }^{2}$ Universidade Federal da Paraíba, Areia, Paraíba, Brasil. \\ ${ }^{3}$ Universidade Federal da Bahia, Escola de Medicina Veterinária e Zootecnia, Salvador, Bahia, Brasil. \\ ${ }^{4}$ Empresa Estadual de Pesquisa Agropecuária da Paraíba, Soledade, Paraíba, Brasil. \\ *Endereço para correspondência: ricardo-zootec@hotmail.com
}

\section{SUMMARY}

The aim of this study was to evaluate the use of silages of different sorghum cultivars through digestibility and nutrient intake and performance of sheep. The experiment was conducted at the Pendência Experimental Station, of the State Company for Agricultural Research of Paraíba S.A. For the experiment, thirty-five rams were used, without defined breed, with average live weight of $17.7 \mathrm{~kg}$, distributed in a completely randomized block design, with five diets and seven replicates to determine intake and performance; and 25 non-castrated rams, without defined breed, distributed in a completely randomized design with five diets and five replicates, to determine the digestibility of nutrients. The average daily intake of dry matter was, on average, $994.66 \mathrm{~g}$. Only the average intakes of ether extract, neutral detergent fiber and non-fibrous carbohydrates, were affected by the diets. The weight gain (WG), feed conversion and feed efficiency of the animals receiving the diets suffered no effect. Silages of BRS 655, 610, 800, 810 and Ponta Negra provided similar intake and digestibility of nutrients. The use of silages of different sorghum cultivars (BRS 610, BRS 655, BRS 800, BRS 810 and Ponta Negra) in diets for confined sheep provide similar performance and intakes.

Keywords: digestibility, nutrients intake, Sorghum bicolor, weight gain

\section{RESUMO}

O objetivo com este estudo foi avaliar a utilização de silagens de diferentes cultivares de sorgo através do consumo, digestibilidade dos nutrientes e desempenho de ovinos. $\mathrm{O}$ experimento foi conduzido na Estação Experimental de Pendência, da Empresa Estadual de Pesquisa Agropecuária da Paraíba S.A. Para o experimento, foram utilizados trinta e cinco carneiros, sem raça definida, com peso vivo médio de $17,7 \mathrm{~kg}$, distribuídos em um delineamento em blocos casualizados, com cinco tratamentos e sete repetições para determinar o consumo e desempenho; e 25 carneiros não castrados, sem raça definida, distribuídos em um delineamento inteiramente casualizado, com cinco tratamentos e cinco repetições, para determinar a digestibilidade dos nutrientes. $\mathrm{O}$ consumo médio diário de matéria seca foi, em média, 994,66 g. Somente os consumos médios de extrato etéreo, fibra em detergente neutro e carboidratos não-fibrosos, foram afetados pelas dietas. $\mathrm{O}$ ganho de peso (GP), conversão alimentar e eficiência alimentar dos animais que receberam as dietas não foram afetados pelos diferentes cultivares utilizados. Silagens de sorgo BRS 655, 610, 800, 810 e Ponta Negra promoveram consumo e digestibilidade de nutrientes semelhantes. A utilização de silagens de diferentes cultivares de sorgo (BRS 610, BRS 655, BRS 800, BRS 810 e Ponta Negra) em dietas para ovinos em 
confinamento promove desempenho e consumo similar.

Palavras-chave: digestibilidade, consumo de nutrientes, Sorghum bicolor, ganho de peso

\section{INTRODUCTION}

Feeding plan is an essential tool to intensify any system of beef cattle production in order to equalize the amount of food supplied and consumed by animals in a sustainable way.

However, the efficient production of forage is the biggest challenge for animal production in Brazilian semiarid region. In the dry season, the limited water supply in this region causes a decrease in plant biomass production, characterizing the seasonality of forage production. Thus, the use of crops that make better use of rainfall as well as store water in their tissues may be of great value to minimize the damaging effects of water shortage.

Sorghum is well adapted to such environments, optimizing the water use efficiency and productivity ratio (PERAZZO et al., 2014). In addition, it has high nutritional value, and its use in animal feed is a cheap option of additional and quality roughage, and which may be used as the sole source of forage.

The use of sorghum in silage form is a viable alternative to increase food supply, mainly for the high dry matter production per area and for the preservation of the original nutrients of crop with low losses during ensilaging. However, it is necessary to observe that the agronomic characteristics of sorghum used, such as grain production, amount of sugars and leaves and leaf/stem ratio may influence the fermentation process, causing variation on nutritional value of silages, influencing animal performance. Silva et al. (2011), when evaluating the agronomic divergence of 25 sorghum hybrids for silage in the state of Paraíba, Brazil, observed values of total dry matter yield from 7.68 to $20.95 \mathrm{Mg} / \mathrm{ha}$, average percentage of stem ranging from 22.95 to 76.19 and average percentage of leaf blade ranging from 5.20 to 14.60. Pinho et al. (2015) reported wide range with water-soluble carbohydrates (ranging from 12.5 to $20.5 \%$ ) and dry matter recovery (ranging from 75.7 to 90.4).

Therefore, the evaluation of different genotypes of sorghum in silage form, which can be cultivated in production systems of the semiarid regions, is of great importance, because it is still unknown the potential use of sorghum genotypes for different purposes, such as forage, grain, or dual purpose, grown in the semi-arid Northeast.

The objective of this study was to evaluate the use of silages of different cultivars of sorghum on digestibility, nutrient intake and performance of sheep.

\section{MATERIALS AND METHODS}

The experiments were conducted at the Pendência Experimental Station, of State Company for Agricultural Research of Paraíba S.A, from August to October 2011.

Two experiments, in which the following cultivars were evaluated in silage form BRS 610, BRS 655, BRS 800, BRS 810 and Ponta Negra, available from the Embrapa Breeding Program were conducted. According to Embrapa, the cultivars BRS 810 and Ponta Negra have forage characteristics, that is, greater production of stem, leaves, and lower grain production. The 
hybrid BRS 610 has dual-purpose characteristics, with good production of grain and stem, and the hybrids BRS 655 and BRS 800 have characteristics of grain sorghum, with higher production of grain and lower production of stem and leaves.

The soil has the following chemical attributes (profile from $0-20 \mathrm{~cm}$ ): $\mathrm{pH}$ : 6.94; P: 70.38; $\mathrm{K}^{+}: 82\left(\mathrm{mg} / \mathrm{dm}^{3}\right) ; \mathrm{Na}^{+}$: $0.37 ; \mathrm{H}^{+}+\mathrm{Al}^{+3}: 2.06 ; \mathrm{Al}^{+3}: 0.0 ; \mathrm{Ca}^{+2}$ : 7.45; $\mathrm{Mg}^{+2}: 2.40 \quad\left(\mathrm{cmolc} / \mathrm{dm}^{3}\right)$, base saturation: $83.51 \%$ and organic matter: $10.55 \mathrm{~g} / \mathrm{kg}$. Soil fertilization was performed with $50 \mathrm{~kg} / \mathrm{ha}$ of $\mathrm{N}$ in the form of ammonium sulfate, 15 days after emergence. Each variety of sorghum was cultivated in 0.1 ha. The spacing of 0.7 $\mathrm{m}$ between rows and a sowing rate of 12 pure seeds viable per linear meter were used. Harvest was done manually when the grains were in milky:pasty state, after 103 days after sowing. The material was chopped in a stationary forage machine, then homogenized and ensiled in 200 liter barrels.

In the first experiment, a randomized block design with five treatments and seven replicates was used. Thus, 35 uncastrated rams, without defined breed, with average live weight of 17.7 $\pm 3.7 \mathrm{~kg}$ were used. The experimental period lasted 42 days after 11 days for adaptation. After the adaptation period, the animals went through a fasting of 12 hours of solid food and then they were weighed, initiating the experimental period. Every 14 days, the animals were weighed again, totaling three periods. After 42 days of the experimental period, the animals were slaughtered, because they all presented, on average, body condition score equal to four. In this case, 42 days were necessary for animals reached the weight and body condition for slaughter. Finally, before slaughter, the animals fasted for 18 hours from solids and were weighed to obtain the final weight.

The animals received five different diets, each of which contained a silage of a sorghum cultivar (Table 1). The diets were composed of silage and concentrate supplement and were formulated to be isonitrogenated and to meet the requirements, according to the NRC (2007), of growing sheep, with an average weight of $18 \mathrm{~kg}$ and a weight gain of $200 \mathrm{~g} /$ day (Table 2).

Table 1. Chemical composition of the ingredients utilized in the experimental diets based on dry matter

\begin{tabular}{|c|c|c|c|c|c|c|c|}
\hline \multirow{2}{*}{ Items } & \multicolumn{7}{|c|}{ Ingredients $^{1}$} \\
\hline & 610 & 655 & 800 & 810 & PN & GC & SM \\
\hline $\operatorname{Dry~matter~}^{2}(\%)$ & 22.46 & 27.12 & 26.95 & 26.67 & 25.12 & 86.73 & 88.08 \\
\hline Organic matter ${ }^{3}(\%)$ & 93.22 & 94.49 & 94.50 & 94.16 & 95.24 & 94.50 & 94.40 \\
\hline Crude protein ${ }^{3}(\%)$ & 3.58 & 5.47 & 5.33 & 5.53 & 4.40 & 8.98 & 45.44 \\
\hline Ether extract ${ }^{3}(\%)$ & 5.60 & 5.91 & 4.44 & 6.11 & 6.88 & 4.15 & 3.51 \\
\hline Neutral detergent fiber ${ }^{3,4}(\%)$ & 51.97 & 46.72 & 47.71 & 48.12 & 54.50 & 11.84 & 13.86 \\
\hline Acid detergent fiber ${ }^{3}(\%)$ & 37.48 & 36.80 & 39.25 & 41.12 & 31.50 & 5.01 & 7.05 \\
\hline $\operatorname{Lignin}^{3}(\%)$ & 5.62 & 5.99 & 4.08 & 2.67 & 4.11 & 1.20 & 1.43 \\
\hline Non-fibrous carbohydrates 3 (\%) & 32.07 & 36.40 & 37.01 & 34.40 & 29.47 & 69.53 & 31.69 \\
\hline $\begin{array}{l}{ }^{2} 610=\text { Sorghum silage BRS610; } \\
\text { Sorghum silage BRS810; PN=S } \\
{ }^{2} \text { Based on natural matter. } \\
\text { 3 Based on dry matter. }\end{array}$ & $\begin{array}{l}\text { Sorghu } \\
\text { silage }\end{array}$ & silage 1 & $\begin{array}{l}\mathrm{S} 655 \\
; \mathrm{GC}=\end{array}$ & $\begin{array}{l}\mathrm{p}=\text { Sor } \\
\text { pund co }\end{array}$ & 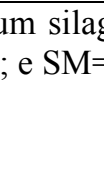 & $\begin{array}{l}\text { BRS80 } \\
\text { oybean }\end{array}$ & $\begin{array}{l}810= \\
\text { heal. }\end{array}$ \\
\hline
\end{tabular}


Rev. Bras. Saúde Prod. Anim., Salvador, v.18, n.3, p.454-464 jul./set., 2017

Table 2. Percentage and chemical composition of the experimental diets

\begin{tabular}{|c|c|c|c|c|c|}
\hline \multirow{2}{*}{ Items } & \multicolumn{5}{|c|}{ Experimental diets $^{1}$} \\
\hline & 610 & 655 & 800 & 810 & PN \\
\hline & \multicolumn{5}{|c|}{ Proportion of ingredients (\%DM) } \\
\hline Silage & 45.11 & 49.62 & 50.98 & 50.85 & 50.15 \\
\hline Corn & 39.07 & 37.83 & 36.25 & 36.18 & 34.66 \\
\hline Soybean & 11.17 & 8.05 & 8.38 & 8.59 & 10.80 \\
\hline Urea & 0.69 & 0.63 & 0.62 & 0.62 & 0.64 \\
\hline Ammonium chloride & 1.01 & 0.93 & 0.90 & 0.90 & 0.81 \\
\hline Mixture mineral $^{2}$ & 2.26 & 2.14 & 2.06 & 2.07 & 2.02 \\
\hline \multirow[t]{2}{*}{ Limestone } & 0.89 & 0.81 & 0.81 & 0.79 & 0.92 \\
\hline & \multicolumn{5}{|c|}{ Chemical composition (\%DM) } \\
\hline Dry matter $^{3}$ & 38.16 & 41.70 & 40.91 & 40.64 & 39.09 \\
\hline Organic matter & 89.52 & 90.25 & 90.35 & 90.19 & 90.72 \\
\hline Mineral matter & 10.48 & 9.75 & 9.65 & 9.81 & 9.28 \\
\hline Crude protein & 13.80 & 13.06 & 12.99 & 13.20 & 13.34 \\
\hline Neutral detergent fiber ${ }^{4}$ & 29.61 & 28.77 & 29.77 & 29.94 & 32.93 \\
\hline Non-fibrous carbohydrates & 45.17 & 46.91 & 46.73 & 45.37 & 42.30 \\
\hline Total carbohydrates & 74.78 & 75.69 & 76.51 & 75.32 & 75.23 \\
\hline Ether extract & 4.54 & 4.79 & 4.06 & 4.91 & 5.27 \\
\hline $\begin{array}{l}{ }^{1} 610=\text { Sorghum silage BRS } \\
\text { Sorghum silage BRS } 810 ; \text { e I } \\
\text { 2Each } 1000 \text { g contains: } 135,0 \\
240 \mathrm{~g} \text {; P } 71 \text { g [solubility in } \\
\text { 10mg; Fe } 2500 \mathrm{mg} \text {; I 40mg; } \\
{ }^{3} \text { Based on dry matter. } \\
{ }^{4} \text { Corrected for ash and prote }\end{array}$ & $\begin{array}{l}\text { hum sila } \\
\text { lage Pon } \\
\text { nin A, } 68 \\
0(\mathrm{~min} .)] \\
15 \mathrm{mg} ; \mathrm{Z}\end{array}$ & $\begin{array}{l}\text { e BRS6 } \\
\text { Negra. } \\
00.00 \mathrm{I} . \\
\mathrm{K} 28.2 \mathrm{~g} \\
1700 \mathrm{~m}\end{array}$ & $\begin{array}{l}5 ; 800= \\
\text { Vitam } \\
20 \mathrm{~g} ; \mathrm{N} \\
\text { Fl max }\end{array}$ & $\begin{array}{l}\text { orghum } \\
\text { D3; } 45( \\
\text { 20g; C } \\
\text { um } 710\end{array}$ & $\begin{array}{l}\text { 3RS800; } 810= \\
\text { vitamin E; Ca } \\
\text { Co 30mg; Cr }\end{array}$ \\
\hline
\end{tabular}

Each animal was vaccinated against clostridial diseases, treated against endoand ectoparasites, supplemented with vitamins $\mathrm{A}, \mathrm{D}$ and $\mathrm{E}$, then housed in individual stalls of $1.2 \times 0.8$, equipped with feeders and drinkers to supply the total diet and water ad libitum.

The animals were fed twice daily, at 7.30 a.m. and 3.30 p.m., individually as a complete mixture, allowing $10 \%$ of leftovers, in order to be ad libitum and the food supply level set correctly. The food and the leftovers were weighed daily to determine the intake of dry matter (DM), organic matter (OM), crude protein $(\mathrm{CP})$, ether extract $(\mathrm{EE})$, neutral detergent fiber corrected for ash and protein (NDFap) and non-fibrous carbohydrate (NFC). For that, samples of diet and leftovers were weekly collected from all animals, individually, and frozen for subsequent analysis.

The daily DM intake was calculated by the difference between total DM offered and total DM in the leftovers, and nutrient intake was calculated by the difference between total nutrients present in the food supplied and the total nutrients present in the leftovers based on total DM.

To find the total weight gain (TWG), average daily gain (ADG), feed conversion (FC) and feed efficiency (FE) the following equations were used:

TWG $=$ Final body weight in fasting initial body weight in fasting.

$\mathrm{ADG}=\mathrm{TWG} / 42$ days.

$\mathrm{FC}=\mathrm{DM}$ intake/ADG.

$\mathrm{FE}=\mathrm{ADG} / \mathrm{DM}$ intake.

Laboratory analyzes were performed at the Laboratory of Animal Nutrition, Federal University of Paraíba - Campus 
II in Areia - PB, where the percentages of DM, OM, mineral matter (MM), CP and $\mathrm{EE}$ were determined, from samples of ingredients of the food and leftovers, as methodologies cited by AOAC (2000). The NDF concentration was corrected for ash and protein (NDFap) which were performed according to Licitra et al. (1996) and Mertens (2002), described by Detmann et al. (2012).

The non-fiber carbohydrates (NFC) concentration was estimated through an adaptation of the equation proposed by Hall (2000): $\mathrm{NCF}=100-[(\% \mathrm{CP}-\%$ $\mathrm{CPu}+\mathrm{U})+\% \mathrm{EE}+\%$ ash NDFap)]; where: $\mathrm{CPU}$ is the $\mathrm{CP}$ content from urea $(\%)$, and $U$ is the urea content (\%).

In the second experiment, the experimental design was completely randomized with five treatments and five replicates. Thus, 25 uncastrated rams, without defined breed, with an average live weight of $17.7 \pm 3.7 \mathrm{~kg}$ were used. The experimental period lasted 21 days with an adaptation period of 14 days.

The treatments were the same five diets containing silages of sorghum genotypes of the first experiment (Table 1 and 2). The daily handling of the animals was also similar to the previous experiment. Therefore, the food was supplied individually, allowing $10 \%$ leftovers, in order to be ad libitum. The food and leftovers were weighed daily to determine the intakes of DM, OM, CP, EE, NDFap and NFC. For this, in the seven days of the collection period, samples of diet and leftovers were collected individually for all animals and frozen for later analysis.

To determine the digestibility of DM, $\mathrm{OM}, \mathrm{CP}, \mathrm{EE}, \mathrm{NDF}$ and $\mathrm{NFC}$, the animals' feces were collected directly at the end of the rectum, on the $15^{\text {th }}, 16^{\text {th }}$, $17^{\text {th }}$ and $18^{\text {th }}$ days at 6 a.m., 12 p.m., 6.00 p.m. and 10 p.m., respectively. Fecal samples were stored at $-15{ }^{\circ} \mathrm{C}$ and subsequently, in the same way as the food and the leftovers, processed at the end of each experimental period.

The estimation of fecal production was performed using the indigestible neutral detergent fiber (iNDF) as the internal indicator. The samples of feces, food and leftovers were incubated in situ for a period of 240 hours (CASALI et al., 2008). The remaining material from the incubation was subjected to extraction with neutral detergent and the residue was considered iNDF. To estimate the fecal production, this equation was used: Feces $\left(\mathrm{g} \mathrm{day}^{-1}\right)=\mathrm{iNDF}$ ingested $/ \mathrm{iNDF}$ concentration in feces.

The digestibility determination was made according to the equation described by Berchielli et al. (2000), where the digestibility coefficient (DC), $\mathrm{g} / \mathrm{kg}$, was calculated by follows: $\mathrm{DC}=$ (ingested nutrient - excreted nutrient) / ingested nutrient $x 100$

Energy value of the diets was estimated using the apparent digestibility obtained in the experiment according the equation proposed by NRC (2001): TDN (\%) = $\mathrm{DNFC}+\mathrm{CPd}+(\mathrm{EED} * 2.25)+\mathrm{DNDF}$

Where " $\mathrm{d}$ " is digestibility, TDN $(\mathrm{g} / \mathrm{kg})=$ total digestible nutrients, $\mathrm{CPd}=$ digestible crude protein; EED = digestible ether extract; DNFC = digestible non-fibrous carbohydrates; DNDF $=$ digestible neutral detergent fiber.

The conversion of TDN values of the diets into digestible energy (DE) and metabolizable energy (ME) was performed with the equations described by NRC (2001): DE (mcal / kg) = $0.04409 *$ DNT $(\%)$; ME (mcal $/ \mathrm{kg})=$ $1.01 * \mathrm{DE}(\mathrm{mcal} / \mathrm{kg})-0.45$

Data of the first and second experiment were subjected to analysis of variance and mean values were compared by Tukey test at the 5\% level of probability, using the Statistical Analysis System SAS (SAS Institute, 2000). 


\section{RESULTS AND DISCUSSION}

There was no significant effect on nutrient intake of dry matter, organic matter, crude protein, non-fibrous carbohydrates, total carbohydrates, neutral detergent fiber and total digestible nutrients, except for the variable ether extract, when evaluated in grams per day (Table 3).

Table 3. Nutrient intake by sheep fed diets containing sorghum silages of different cultivars

\begin{tabular}{|c|c|c|c|c|c|c|c|}
\hline \multirow{2}{*}{$\begin{array}{l}\text { Items }^{2} \\
\text { Grams/day }\end{array}$} & \multicolumn{5}{|c|}{ Experimental diets $^{1}$} & \multirow{2}{*}{ Average } & \multirow{2}{*}{$\mathrm{CV} \%{ }^{3}$} \\
\hline & 610 & 655 & 800 & 810 & $\mathrm{PN}$ & & \\
\hline $\mathrm{DM}^{4}$ & 916.82 & 1005.96 & 1027.66 & 1041.07 & 981.82 & 994.66 & 11.18 \\
\hline $\mathrm{OM}$ & 816.36 & 903.72 & 925.40 & 934.54 & 885.37 & 893.08 & 11.26 \\
\hline $\mathrm{CP}$ & 132.69 & 139.19 & 138.69 & 143.38 & 139.07 & 138.61 & 10.79 \\
\hline NDF & 241.96 & 253.88 & 279.23 & 290.96 & 293.86 & 271.98 & 13.20 \\
\hline NFC & 434.38 & 496.35 & 499.98 & 483.78 & 431.36 & 469.17 & 10.48 \\
\hline $\mathrm{TC}$ & 676.34 & 750.23 & 779.22 & 774.74 & 725.25 & 741.16 & 11.38 \\
\hline $\mathrm{EE}$ & $43.76^{\mathrm{b}}$ & $50.83^{\mathrm{ab}}$ & $43.33^{\mathrm{b}}$ & $53.70^{\mathrm{a}}$ & $54.86^{\mathrm{a}}$ & 49.30 & 10.26 \\
\hline TDN & 595.00 & 624.47 & 654.03 & 659.84 & 592.62 & 623.97 & 9.29 \\
\hline $\begin{array}{l}\text { Items } \\
\text { Grams/kg de }{ }^{5} \mathrm{BW}\end{array}$ & 610 & 655 & 800 & 810 & PN & & \\
\hline DM & 42.60 & 45.03 & 46.40 & 47.13 & 45.10 & 45.25 & 8.63 \\
\hline OM & 37.91 & 40.46 & 41.77 & 42.31 & 40.71 & 40.63 & 8.70 \\
\hline $\mathrm{CP}$ & 6.16 & 6.23 & 6.26 & 6.49 & 6.40 & 6.31 & 8.42 \\
\hline NDF & $11.23 \mathrm{c}$ & $11.34^{b c}$ & $12.60^{\mathrm{abc}}$ & $13.16^{\mathrm{ab}}$ & $13.49^{\mathrm{a}}$ & 12.36 & 10.06 \\
\hline NFC & 20.20 & 22.24 & 22.57 & 21.89 & 19.86 & 21.35 & 8.34 \\
\hline $\mathrm{TC}$ & 31.43 & 33.59 & 35.17 & 35.07 & 33.33 & 33.72 & 8.77 \\
\hline $\mathrm{EE}$ & $2.04^{\mathrm{bc}}$ & $2.27^{\mathrm{ab}}$ & $1.96^{\mathrm{c}}$ & $2.44^{\mathrm{a}}$ & $2.51^{\mathrm{a}}$ & 2.25 & 8.27 \\
\hline TDN & 27.58 & 27.92 & 29.64 & 29.67 & 27.48 & 28.43 & 10.25 \\
\hline $\begin{array}{l}\text { Items } \\
\text { Grams/kg BW }\end{array}$ & 610 & 655 & 800 & 810 & PN & & \\
\hline $\mathrm{DM}$ & 91.66 & 97.84 & 100.63 & 102.10 & 97.37 & 97.92 & 8.54 \\
\hline OM & 81.62 & 87.90 & 90.61 & 91.65 & 87.84 & 87.92 & 8.61 \\
\hline $\mathrm{CP}$ & 13.26 & 13.54 & 13.58 & 14.06 & 13.81 & 13.65 & 8.24 \\
\hline NDF & $24.17^{\mathrm{c}}$ & $24.67^{b c}$ & $27.33^{\mathrm{abc}}$ & $28.54^{\mathrm{ab}}$ & $29.11^{\mathrm{a}}$ & 26.76 & 10.21 \\
\hline NFC & $43.45^{\mathrm{a}}$ & $48.29^{\mathrm{ab}}$ & $48.97^{\mathrm{ab}}$ & $47.44^{\mathrm{ab}}$ & $42.83^{\mathrm{b}}$ & 46.20 & 8.10 \\
\hline $\mathrm{TC}$ & 67.62 & 72.97 & 76.30 & 75.98 & 71.94 & 72.96 & 8.72 \\
\hline $\mathrm{EE}$ & $4.38^{b c}$ & $4.95^{\mathrm{ab}}$ & $4.25^{\mathrm{c}}$ & $5.27^{\mathrm{a}}$ & $5.45^{\mathrm{a}}$ & 4.86 & 8.07 \\
\hline TDN & 59.43 & 60.66 & 64.22 & 64.38 & 59.18 & 61.50 & 9.27 \\
\hline
\end{tabular}

Means followed by same letter in line do not differ by Tukey test $(\mathrm{P}>0.05)$.

${ }^{1} 610=$ Sorghum silage BRS610; 655= Sorghum silage BRS655; 800= Sorghum silage BRS800; $810=$ Sorghum silage BRS810; e PN= Sorghum silage Ponta Negra.

${ }^{2}$ Dry matter, Organic matter, Crude protein, neutral detergente fiber, non-fibrous carbohydrates, Total carbohydrates, Ether extract, Total digestible nutriente.

${ }^{3}$ Coefficient of variation.

${ }^{4}$ Based on natural matter.

${ }^{5}$ Body Weight. 
The DM intake was 36\% higher than that estimated by the NRC (2007) for sheep with the same body weight and weight gain in this experiment. The $\mathrm{CP}$ intake recommended by the NRC (2007) for sheep with the same body weight and weight gain in this experiment is $95.32 \mathrm{~g} /$ day. The animals' CP intake was, on average, 138.61 $\mathrm{g} /$ day, higher than the recommended. This was due to fact that the DM intake was higher than the estimated.

When evaluating intake through body weight (BW) and metabolic weight (BW ${ }^{0.75}$ ), there was no significant results for the variables mentioned above (Table 3), except for NDF and $\mathrm{EE}$ for evaluation of body weight and NDF, NFC and EE in metabolic weight. In Table 3, it is noted that the ether extract intake was greater for animals fed BRS 810 and Ponta Negra than BRS 610 and BRS 800 and the NDF intake was greater for animals receiving BRS800, BRS810 and Ponta Negra than BRS 610, since the greatest ether extract intake and neutral detergent fiber may be associated with genotypes that have higher concentrations of these nutrients in the diet (Table 2). Therefore, as the diets did not affect dry matter intake (DMI), it is noted that the animals consumed a higher amount of $\mathrm{EE}$ and NDF due to the higher percentage of these nutrients in the diet. However, the different intakes of these nutrients were not enough to affect the TDN intake.

According to Van Soest (1994), the NDF intake between $0.8-1.2 \%$ of body weight maximizes the DM intake. The NDF intakes of animals submitted to diets were all close to $12 \mathrm{~g} / \mathrm{kg}$ (Table 3 ), which corresponds to a percentage of $1.2 \%$ BW. Thus, all diets allowed the maximization of the animals' intake, which were not affected by physical limitations due to excess of fiber or high energy concentration.

The intake of non-fiber carbohydrates (NFC), when measured in metabolic weight $\left(\mathrm{BW}^{0.75}\right)$, also had significance, knowing that the diet containing silage of the genotype 610 had higher intake compared with the diet containing silage of the genotype Ponta Negra. There was no significant difference between these diets and the others $(655$, 800 , and 810). It was noted that the diets with higher intakes of NFC in metabolic weight, had higher levels of these nutrients in their composition (Table 2).

The performance was not affected $(\mathrm{P}<0.05)$ by the experimental diets (Table 4). The final body weight, total weight gain and average daily gain did not differ $(\mathrm{P}<0.05)$ among animals, averaging 26.24 $\mathrm{kg}, \quad 8.49 \mathrm{~kg}$ and $202.18 \mathrm{~g} /$ day, respectively. No significant differences $(\mathrm{P}<0.05)$ was found for feed conversion (4.98 kg DM/kg of BW) and feed efficiency $(0.204 \mathrm{~kg}$ BW/ $\mathrm{kg}$ of $\mathrm{DM})$ variables. Diets were formulated in a way to meet gains of $200 \mathrm{~g}$ of body weight daily for all animals, and this fact associated with no longer variation in their composition (Table 1) contributed to absence of difference in the performance. In all treatments, the ADGs were near $200 \mathrm{~g}$, because all diets made up the nutrient requirements estimated by the NRC (2007). This shows that even when using silages of sorghum with different characteristics, it is possible to balance the food in order to overcome their nutritional differences, thus, having the animals achieve the same performance. 
Table 4. Performance of sheep fed diets containing sorghum silages of different cultivars

\begin{tabular}{lccccccc}
\hline \multirow{2}{*}{ Items } & \multicolumn{9}{c}{ Experimental diets $^{1}$} & \multicolumn{2}{c}{ Average } & $\begin{array}{c}\text { CV } \\
\%\end{array}$ \\
\cline { 2 - 6 } & 610 & 655 & 800 & 810 & PN & 17.74 & 9.99 \\
Initial body weight $(\mathrm{kg})$ & 17.34 & 18.11 & 17.91 & 17.80 & 17.57 & 17.9 \\
Final body weight (kg) & 25.69 & 26.77 & 26.29 & 26.54 & 25.91 & 26.24 & 9.04 \\
Total weight gain (kg) & 8.343 & 8.657 & 8.371 & 8.743 & 8.343 & 8.49 & 16.14 \\
Weight gain (g/dia) $^{2}$ & 198.64 & 206.12 & 199.32 & 208.16 & 198.64 & 202.18 & 16.14 \\
Feed conversion $^{2}$ & 4.66 & 4.92 & 5.23 & 5.07 & 5.02 & 4.98 & 12.38 \\
Feed efficiency $^{3}$ & 0.22 & 0.20 & 0.20 & 0.20 & 0.20 & 0.20 & 12.28 \\
\hline
\end{tabular}

${ }^{\mathrm{T}} 610=$ Sorghum silage BRS610; $655=$ Sorghum silage BRS655; 800= Sorghum silage BRS800; $810=$ Sorghum silage BRS810; e PN= Sorghum silage Ponta Negra.

${ }^{2} \mathrm{~kg}$ of dry matter $/ \mathrm{kg}$ of weight gain daily.

${ }^{3} \mathrm{~kg}$ of weight gain daily $/ \mathrm{kg}$ of dry matter.

No implication was found from DM, $\mathrm{OM}, \mathrm{CP}, \mathrm{EE}$ and NFC variables on the digestibility and metabolizable energy (ME) in the experimental diets (Table 5). The diet containing BRS 800 silage had higher neutral detergent fiber digestibility than the diet containing BRS 655 silage (Table 5). However, there was no significant difference between these diets and the others.

Several factors influence the fiber digestibility, among them is the greater presence of non-fibrous carbohydrates.
According to Paulino et al. (2004), depression in rumen digestibility of fibrous components from forage can lead to longer retention of fibrous residues in the rumen and usually reduce forage intake, since the greater the amount of non-fibrous carbohydrates, the lower fiber digestibility. It's worth to highlight that difference showed in apparent digestibility of diets containing BRS 655 and BRS 800 was not expected, due their similar NFC and NDF composition, and their intake similarity by animals.

Table 5. Apparent digestibility of the nutrients in sheep fed with sorghum silages of different cultivars

\begin{tabular}{|c|c|c|c|c|c|c|c|}
\hline \multirow{2}{*}{ Items $^{2}$} & \multicolumn{5}{|c|}{ Experimental diets $^{1}$} & \multirow{2}{*}{ Average } & \multirow{2}{*}{$\begin{array}{l}\mathrm{CV} \\
\%^{3}\end{array}$} \\
\hline & 610 & 655 & 800 & 810 & $\mathrm{PN}$ & & \\
\hline $\mathrm{DM}^{4}$ & 57,89 & 57,70 & 60,98 & 57,87 & 54,59 & 57,81 & 7,86 \\
\hline $\mathrm{OM}$ & 62,05 & 59,59 & 63,21 & 59,86 & 57,62 & 60,38 & 6,23 \\
\hline $\mathrm{CP}$ & 72,92 & 67,46 & 72,14 & 69,39 & 67,65 & 69,92 & 5,16 \\
\hline NDF & $20,41^{\mathrm{ab}}$ & $15,67^{\mathrm{b}}$ & $31,13^{\mathrm{a}}$ & $20,00^{\mathrm{ab}}$ & $18,92^{\mathrm{ab}}$ & 21,44 & 27,88 \\
\hline NFC & 83,55 & 82,94 & 84,52 & 84,25 & 86,06 & 84,31 & 5,85 \\
\hline $\mathrm{EE}$ & 75,97 & 73,80 & 74,52 & 78,30 & 78,18 & 76,44 & 6,27 \\
\hline $\mathrm{ME}, \mathrm{Mcal} / \mathrm{kg}$ & 2,24 & 2,15 & 2,34 & 2,23 & 2,15 & 2,22 & 5,54 \\
\hline
\end{tabular}

${ }^{1} 610=$ Sorghum silage BRS610; 655= Sorghum silage BRS655; 800= Sorghum silage BRS800; 810= Sorghum silage BRS810; e PN= Sorghum silage Ponta Negra.

${ }^{2}$ Dry matter, Organic matter, Crude protein, neutral detergente fiber, non-fibrous carbohydrates, Total carbohydrates, Ether extract, Metabolizable energy.

${ }^{3}$ Coefficient of variation.

${ }^{4}$ Based on natural matter.

Means followed by same letter in line do not differ by Tukey test $(\mathrm{P}>0.05)$ 
Although the differences in purpose of cultivars (forage and dual-purpose) have provided differences in silages composition, especially in relation to the neutral detergent fiber, non-fibrous carbohydrates, ether extract and crude protein concentration, the diet balancing was able to reduce these differences. This can be proved by the nonsignificance on intake, performance and digestibility of most nutrients.

Importantly, some authors like Cabral Filho et al. (2013) indicate sorghum cultivars with high grain production (grain sorghum) as being primordial in the formulation of diets for confined sheep.

Perazzo (2017) and Silva et al. (2011) found that forage sorghum are more productive than grain sorghum when grown in the semiarid Paraiba, with same crop treatments, concluding that the forage sorghum would have a lower production cost, expressed per kilogram of dry matter produced. Correlating with the present study, in which the animals had similar gains when receiving diets of silage from different cultivars, without changes in the amount of concentrate supplied, the use of forage sorghum cultivars could be more economically viable, due to its highest potential yield, reducing production costs and increasing the capacity of a forage support in cultivated areas.

The present study was important for the observations of Candido et al. (2015), which continued the research evaluated the costs of production and the economic return of the finishing system in confinement of sheep with silage of different sorghum cultivars. The authors concluded that the cultivar 'BRS 810' had lower production costs and higher net income per carcass, due to the higher production of dry matter per hectare of this cultivar, increasing the forage support capacity of the cultivated areas, allowing more animals to be confined.

Hence, at the choice of sorghum cultivar to be used in the silage production destined to the sheep feeding, the productivity characteristics and production costs of cultivars become of great importance in semiarid regions.

The use of different sorghum cultivars silages (BRS 610, BRS 655, BRS 800, BRS 810 and Ponta Negra) in diets for confined sheep provide similar performance, nutrient intake and digestibility. Therefore, all these sorghum cultivars may be used for feeding sheep, in silage form. Due to this similarity, one should choose the cultivars with the lowest cost of production.

\section{REFERENCES}

ASSOCIATION OF OFFICIAL ANALYTICAL CHEMISTS - AOAC. Official methods of analysis of AOAC International. 17th ed. Gaithersburg, MD, USA, 2000.

CABRAL FILHO, S.L.S.; ABDALLA, A.L.; BUENO, I.C.S.; GOBBO, S.P.; OLIVEIRA, A.A.M. Effect of sorghum tannins in sheep fed with highconcentrate diets. Arquivo Brasileiro de Medicina Veterinária e Zootecnia, v.65, n.6, p.1759-1766, 2013.

CÂNDIDO, E.P.; SANTOS, E.M.; RAMOS, J.P.F.; Oliveira, J.S.; PINHO, R.M.A.; PERAZZO, A.F.; RAMOS, R.C.S.; FREITAS, P.M.D. Economic response of feedlot sheep fed silages with different cultivars of sorghum. Ciência Rural, v.45, p.79-85, 2015. 
CASALI, A.O.; DETMANN, E.; VALADARES FILHO, S.C.; PEREIRA, J.C.; HENRIQUES, L.T.; FREITAS, S.G.; PAULINO, M.F. Influence of incubation time and particles size on indigestible compounds contents in cattle feeds and feces obtained by in situ procedures. Revista Brasileira de Zootecnia, v.37, p.35342, 2008.

DETMANN, E.; SOUZA, M.A.; VALADARES FILHO, S.C.; QUEIROZ, A.C.; BERCHIELLI, T.T.; SALIBA, E.O.S.; CABRAL, L.S.; PINA, D.S.; LADEIRA, M.M.; AZEVEDO, J.A.G. Métodos para análise de alimentos. (INCT - Ciência animal). Viçosa, MG: Universidade Federal de Viçosa, 2012. 214p.

HALL, M.B. Calculation of nonstructural carbohydrate concentration of feeds that contain non-protein nitrogen. Gainesville: University of Florida, 2000. p.A-25. (Bulletin, 339).

LICITRA, G.; HERNANDEZ, T.M.; VAN SOEST, P.J. Standardization of procedures for nitrogen fractionation of ruminant feeds. Animal Feed Science and Technology, v.57, p.347-358, 1996.

MERTENS, D.R. Gravimetric determination of amylase-treated neutral detergent fiber in feeds with refluxing in beakers or crucibles: collaborative study. Journal of AOAC International, v.85, p.1217-1240, 2002.

NATIONAL RESEARCH COUNCIL NRC. Nutrient Requirements of Dairy Cattle. 7th Revised Edition. Washington, D.C.: National Academy Press, 2001.
NATIONAL RESEARCH COUNCIL NRC. Nutrient requirements of small ruminants. Washington, D.C.: National Academy Press, 2007.

PAULINO, M.F.; FIGUEIREDO, D.M.; MORAES, E.H.B.K.; PORTO, M.O.; SALES, M.F.L.; ACEDO, T.S.; VILLELA, S.D.J.; VALADARES FILHO, S.C. Suplementação de Bovinos em pastagens: uma visão sistêmica. In: SIMPÓSIO DE PRODUÇÃO DE GADO DE CORTE, 2004, Viçosa, MG. Anais... Viçosa, MG, 2004. p.93-144.

PERAZZO, A.F.; CARVALHO, G.G.P.; SANTOS, E.M.; PINHO, R.M.A.; CAMPOS, F.S.; MACEDO, C.H.O.; AZEVÊDO, J.A.G.; TABOSA, N.T. Agronomic evaluation of 32 sorghum cultivars in the Brazilian semiarid region. Revista Brasileira de Zootecnia, v.43, p.232-237, 2014.

PERAZZO, A.F.; CARVALHO, G.G.P.; SANTOS, E.M.; BEZERRA, H.F.C.; SILVA, T. C.; PEREIRA, G.A.; RAMOS, R.C.S.; RODRIGUES, J.A.S. Agronomic Evaluation of Sorghum Hybrids for Silage Production Cultivated in Semiarid Conditions. Frontiers in Plant Science, v.8, p.1-8, 2017.

PINHO, R.M.A.; SANTOS, E.M.; OLIVEIRA, J.S.; BEZERRA, H.F.C.; FREITAS, P.M.D.; PERAZZO, A.F.; RAMOS, R.C.S.; SILVA, A.P.G. Sorghum cultivars of diferente purposes silage. Ciência Rural, v.45, n.2, p.298303, 2015.

SILVA, T.C.; SANTOS, E.M.; AZEVEDO, J.A.G.; EDVAN, R.L.; PERAZZO, A.F.; PINHO, R.M.A.; RODRIGUES, J.A.S.; SILVA, D.S. Agronomic divergence of sorghum hybrids for silage yield in the semiarid 
region of Paraiba. Revista Brasileira

de Zootecnia, v.40, p.1886-1893, 2011.

STATISTICAL ANALYSES SYSTEM

- SAS. SAS/STAT User's guide. Cary:

STATS. 2000.

VAN SOEST, P.J. Nutritional ecology of the ruminant. $2^{\text {nd }} \mathrm{Ed}$. Ithaca, New York: Comstock Publishing Associates, 1994.

Data de recebimento: 07/07/2016

Data de aprovação: 15/08/2017 